Open Access

\title{
Fostering innovation in social work and social education degrees: multilingual environment and tools for social change
}

\author{
Maria Tereza L. Cavalcante*, Gisela Riberas and Genoveva Rosa
}

\author{
* Correspondence: \\ mtleal@peretarres.org \\ Facultat d'Educació Social i Treball \\ Social Pere Tarrés, Universitat \\ Ramon Llull, Carrer de Santaló, 37, \\ 08021 Barcelona, Spain
}

\begin{abstract}
The article presents an innovative educative experience in higher education in Spain that combines methodology, content and new technologies in a multilingual environment. It presents an experience of implementing a subject called International Perspectives on Social Innovation in Social Work and Social Education degrees. By using the Content and Language Integrated Learning (CLIL) model, the subject aimed to promote problem-solving and creative thinking among students. To this end, students developed a project using Appreciative Inquiry (Al), a tool used to promote change and innovation in organizations. The objective was to provide a broader outlook on social intervention or social action and to enhance student's knowledge and their willingness to build society and shape key values. In order to accomplish its goals, the subject fostered the use of innovative ideas and technologies and offered a multilingual working environment. Results have shown a predisposition to adopt new technologies in their professional life as the final products reflected a very positive image of the perspectives of innovations in the social sector as well as their willingness to innovate as future professionals.
\end{abstract}

Keywords: Innovation, Educational Technologies, Higher education, Social innovation, Content and language integrated learning, Appreciative inquiry

\section{Introduction}

The present article sets out the experience of implementing a new subject called International Perspectives on Social Innovation offered to Social Work and Social Education students at a Spanish university.

Evidently, as participants in the Bologna Process, Spanish universities are committed to the European effort to ensure more comparable, compatible and coherent systems of higher education. This effort includes not only curriculum design and quality procedures, but also the strengthening of aspects of language competence among teachers and students in order to favour mobility. Students and teacher are expected to be competent in at least one foreign language used at the European level, but though many universities in Spain have been promoting the use of English as a second language, the fact is that only one in ten Spanish students has the self-perception of having an advanced level of English (OCU, 2013).

(c) 2016 The Author(s). Open Access This article is distributed under the terms of the Creative Commons Attribution 4.0 International License (http://creativecommons.org/licenses/by/4.0/), which permits unrestricted use, distribution, and reproduction in any medium, provided you give appropriate credit to the original author(s) and the source, provide a link to the Creative Commons license, and indicate if changes were made. 
Spanish's universities have been addressing this challenge in different ways or from different perspectives. Halbach and Lazaro (2015) found in their study a great deal of heterogeneity among the different higher education institutions, as well as multiple systems for assessing and accrediting the students' command of English.

One common practice is to demand the B2 or B1 European language level as a formal requirement for the enrollment or for the final certificate. Indeed, in some autonomous communities of Spain, such as Catalonia, the B2 accreditation is already a legal requirement for granting the diploma (Llei 2/2014, Article 211). Another way of increasing the student's competence in English is through the inclusion of English classes, provided by language institutes or international departments at universities.

At the same time, due to other requirements of the European Higher Education Area, Spanish faculties are also investing in their curriculum design and reshaping the study plan, introducing English within their subjects and content. There is a double interest in doing so: to improve English Competence among Spanish students and to offer an attractive study plan to foreign students, especially for incoming students under the Erasmus Programme.

In this context, the "Pere Tarrés Social Educaton and Social Work Faculty" from Universitatt Ramon Llull in Barcelona included in the study plan of its degrees a subject that aims to improve students' communication skills in English.

This subject was initially called "English for Social Workers"/"English for Social Educators", a mandatory 3 ECTS course for third-year students. It had been taught during 3 consecutive years and focused on basic communication skills and professional vocabulary. However, results were far from satisfactory, as students with high-level English competence considered it too basic, and students with a low level of English failed to show any motivation or improvement.

The biggest challenge was how to motivate both groups of students, since it was not possible to separate them according to English levels because students with a B2 level accounted for less than $10 \%$ of the class. Proposals that students produce essays and presentations were met with complaints and a widespread feeling of "we can't do it", making it very hard to maintain motivation and attendance. Moreover, Spanish students suffer from a belief that they speak English badly and participation in class was hard to achieve, as students' concerns were focused on the stress of making an oral intervention in English.

There was a clear need for change, and not only in the approach to language. The Social Work and Social Education professions had been challenged to respond to the recent consequences of the economic crisis. Both professions had grown with the support of extended social policies during the consolidation of the Social Welfare State, but the recent economic crisis placed them in a new scenario in which classical models of intervention were inadequate when it came to addressing the new social needs (Mulgan, 2007). Both degrees should prepare professionals to go beyond the traditional ways of promoting social action and delivering social services, which brought the need to foster innovation and creativity to the university.

Parallel to this scenario, the faculty was also concerned to comply with other European quality standards; for instance, assuring that subjects were delivered in a way that encouraged students to take an active role in creating the learning process (ESG, 2015). The participation of our faculty in Erasmus Intensive Programmes 
(the formers IPs) also contributed to closer contact with innovative methodologies and pedagogical proposals. The Intensive Programme on Wellbeing and Economic Growth, held in Antwerp, Belgium in March 2014 was particularly inspiring (Lievens, 2014). The programme, coordinated by Karel de Grote University College (KdG), had a very innovative approach and was a major influence on the introduction of methodological changes in our programme.

Those were the precedents for the development of a new compulsory subject for third year students: International Perspectives on Social Innovation. This replaced the previous English subject, while maintaining the same 3 ECTS and retaining English as the principal language. The objective of the new course was to provide a broader outlook on social intervention or social action and to enhance student's knowledge and their willingness to build society and shape key values such as solidarity, family-values, freedom, entrepreneurship and identity. Although improving English Competences was not among the main objectives, we adopted the Content and Language Integrated Learning (CLIL) approach, in which content and language share the same relevance in class (Marsh, 2001).

CLIL implies a dual-focused education with two main aims: one related to the content, topic, or theme, and the other linked to the language (Marsh, 2001). It is also evident that CLIL encourages teachers to take risks and to experiment, favouring teaching innovation (Lasagabaster \& Ruiz de Zarobe, 2010). From the student point of view, CLIL is a positive approach to enhancing English competence as it helps them develop a positive 'can do' attitude towards themselves as language learners (Marsh, 2001).

Nonetheless, the new subject goes beyond the theoretical understanding of the concept of social innovation in a second language. It challenges students to think about our current social welfare crisis, with a prospective approach to the issue. In addition to CLIL we decided to use Appreciative Inquiry (AI), a tool used to promote change and innovation in organizations. This tool, a sequence of methodological steps to inspire, mobilize and sustain significant change (Cooperrider \& Whitney, 2001), was successfully adopted at the previous IP experience.

International Perspectives on Social Innovation approaches a number of social innovation initiatives currently being designed, tested or used to promote social wellbeing and economic growth around the world. Students are invited to take a deeper look into significant aspects of the process of developing innovative solutions to common needs such as the innovation process, technologies, creativity, leadership and funding.

The main competences to be achieved were:

1. The capacity to identify and describe Social Innovation, with special attention to the innovation process, the technologies and skills involved and the key factors in different social innovation initiatives around the world.

2. The development of creative thinking and envisioning

As learning results, we expected students:

$\checkmark$ To identify international initiatives of Social Innovation

$\checkmark$ To describe the innovation process and the concepts of social innovation 
$\checkmark$ To take into account factors such as technologies, leadership, envisioning, personal competences, management and networks.

$\checkmark$ To identify key factors that may enable social innovations to be replicable in different contexts

The Assessment model:

This was a competence oriented course and we used the Continuous Assessment evaluation approach. Assignments were designed to measure the level of achievement of each competence and the respective learning goals. Students had supervision and tutoring all course long and had to deliver intermediate tasks to show evidences of their progress.

Two main assignments were set:

1. Research on Social Innovation Initiatives: a personal essay, to be delivered in English, on a social innovation of their interest. This individual assignment accounted for $30 \%$ of the final grade.

A. Appreciative Inquiry Project Development: a group activity to be developed throughout the course, with the delivery of 3 intermediate tasks and a final media product (a video or audio in English for publication on the Internet). This was the main project and the current object of our attention in this article. It accounted for $70 \%$ of the final grade.

For each assignment there was an assessment guideline, a standard document of our faculty that clarifies the assessment criteria, the grading system, the expected results and the deadlines. Besides, the subject's Syllabus related each competences to its learning activities and learning results (Table 1).

\section{Method}

The subject, which ran from January to May, 2015 in 15 sessions of $1.5 \mathrm{~h}$ each, had 115 students enrolled in three groups, with no assessment of their English level. Two groups were from the Social Education degree with 79 students and the third one was

Table 1 Competences and learning results

\begin{tabular}{|c|c|c|c|}
\hline Competences & Learning activities & Learning results & Assessment activities \\
\hline $\begin{array}{l}\text { 1. The capacity to identify } \\
\text { and describe Social } \\
\text { Innovation, with special } \\
\text { attention to 1) the } \\
\text { innovation process, 2) } \\
\text { the skills involved and 3) } \\
\text { the key factors of } \\
\text { different social } \\
\text { innovation initiatives } \\
\text { around the world. }\end{array}$ & $\begin{array}{l}\text { Practical and theoretical } \\
\text { Classes } \\
\text { Case Analysis }\end{array}$ & $\begin{array}{l}\text { To identify international } \\
\text { initiatives of Social } \\
\text { Innovation } \\
\text { To describe the innovation } \\
\text { process and the concepts } \\
\text { of social innovation } \\
\text { To identify the main skills } \\
\text { required } \\
\text { To identify key factors to } \\
\text { be replicable. }\end{array}$ & $\begin{array}{l}\text { Research on Social } \\
\text { Innovation Initiatives } \\
30 \% \text { of final grade }\end{array}$ \\
\hline $\begin{array}{l}\text { 2. To develop creative } \\
\text { thinking and envisioning }\end{array}$ & $\begin{array}{l}\text { Workshop sessions } \\
\text { Appreciative Inquiry } \\
\text { Methodology }\end{array}$ & $\begin{array}{l}\text { To take into account factors } \\
\text { such as leadership, } \\
\text { envisioning, personal } \\
\text { competences, management } \\
\text { and networks. } \\
\text { To create visions }\end{array}$ & $\begin{array}{l}\text { Appreciative Inquiry } \\
\text { Project Development } \\
70 \% \text { of final grade }\end{array}$ \\
\hline
\end{tabular}

Note: Reprinted from Cavalcante M.T.L (2014). International Perspectives on Social Innovation 
from the social work degree, with 36 students. Most students were Spanish, with the exception of one Erasmus student from Belgium and several students from Latin America. All of them were third year students and most were already doing their first internships, working $10 \mathrm{~h}$ a week at social services institutions, penitentiary facilities, non-governmental organizations and health services such as hospitals and primary care centres, among others.

The subject was defined as an Active Learning course, which means that it focuses the responsibility for learning on the learners (Bean, 2011; Lievens, 2014). The teacher's role was to provide guidance throughout the learning process, but students were expected to combine personal initiative and self-mastery as well as teamwork skills to work together.

Attendance was a mandatory requirement (85\% was the minimum rate) and English the main language. Moodle provided the multilingual platform for sharing content and delivering essays. In addition to the usual learning platform, a Facebook page was created to share content in a collaborative way.

All content material and literature were in English and the final essays were to be delivered in English. In class, students could address the teacher in English, Spanish or Catalan. The teacher would speak English or Spanish, and, given the disparity of English levels in class, Spanish was a useful resource for ensuring comprehension. CLIL supplied the basis of the pedagogical relationship in terms of assuring motivation and ensuring students would feel invited to enjoy the class and share material on line, regardless of their English level. Facebook content was in both English and Spanish and Moodle Forums were also bilingual.

\section{Appreciative Inquiry (AI) as a learning methodology}

AI has been proven to be a useful resource that overcomes the traditional "problem solving" approach, usually centred on problem identification, analysis of probable causes and definition of possible solutions. The Appreciative Inquiry approach suggests "that organizations, as centers of human relatedness, are 'alive' with infinite constructive capacity" (Cooperrider \& Whitney, 2001, p. 3) and this is why the method implies "the art and practice of asking questions that strengthen a system's capacity to apprehend, anticipate, and heighten positive potential" (p. 3). It seemed to be the most appropriate tool for stimulating students to think about the future of professions challenged by the economic and social crisis.

The objective of the AI Project was to promote problem solving and creative thinking, as well as content assimilation. We used an adapted version of its 4-D Cycle in order to think of possible scenarios for Social Education and Social Work in Spain 20 years from now.

The 4D Cycle is a tool with 4 steps for promoting change and improvement. First it identifies moments of peak performance in an organization or area in order to appreciate the tacit knowledge of what works well, known as the "Discovery Phase". This is followed by a sequence of envisioning inspired by the positive inputs of the previous step. The result of this "Dreaming Phase" is a positive vision of the organization's future. The next sequence is a "Design Phase" to make explicit a concrete planning process with which to achieve this vision. Finally, the "Delivery Phase" involves the implementation of the plan (Cooperrider \& Whitney, 2001; Newton \& Hartley, 2005). 
We applied the 4-D Cycle in order to think of possible scenarios for Social Education and Social Work in the Spanish or Catalan Context. Students were invited to develop and present a project in which they would:

- Explore what is really working well in their field in a positive way (discovery phase).

- Think of how they would like this field to be 20 years from now (dreaming phase).

- Design how they would achieve this vision (design phase).

- Deliver a final product on the Internet expressing their idea (destiny phase).

Students had to work in small groups of 4 to 5 people. They were expected to deliver 3 intermediate tasks (Discovery, Dream and Design) and a final product - a video or a web presentation to be published on the Internet in English, expressing their Destiny phase. All intermediate tasks were assessed and graded separately, using the Continuous Assessment approach (Table 2). Supervision and tutoring were offered in each phase to assure the accomplishment of requirements before moving to the next step.

For each task we provided a specific guideline. Students were allowed to deliver all intermediate tasks (Discovery, Dream and Design) in Spanish, but the Destiny delivery had to be in correct English.

To achieve the objective of this assignment, students had to ensure that at least one member of their group was fluent in written and oral English, search for and agree on a social context of interest to them, plan the way they would work, define a schedule and deliver all four tasks. The methodological steps adopted for each of the phases are described below:

\section{A. Discovery Phase:}

The first step was literally to carry out an appreciative inquiry into what is really working well in the social education/social work field. Students were invited to make contact with a professional and interview him or her. Each student had to conduct at least one interview and the group had to deliver a summary of the main conclusions of the interview process, in English, Spanish or Catalan. All of the questions were given in English, but the interview could be carried out in Spanish or Catalan (Table 3). Questions were oriented towards obtaining positive inputs regarding the issue (see Table 1). After all of the groups had concluded the interview phase, they were invited to share their findings orally in class, in English, Spanish or Catalan. This contributed to identifying the positive aspects of the profession that would inspire and motivate the next phase.

Table 2 Intermediate tasks

\begin{tabular}{lc}
\hline Task & Weight \\
\hline Discovery & $10 \%$ \\
Dream & $15 \%$ \\
Design & $15 \%$ \\
Destiny & $30 \%$ \\
\hline
\end{tabular}

Note: Reprinted from Cavalcante M.T.L (2014). International Perspectives on Social Innovation. Assessment Guidelines 
Table 3 Interview questions

1. Could you tell me the best experience you have ever had as a social educator/social worker?

2. Why was it so good?

3. What is the best thing you have ever done as a social educator/social worker?

4. What kind of feelings do you associate with this experience?

5. What is the thing that social educators/social workers do best?

6. What do you think is the best thing about being a social educator/social worker?

7. What is THE attitude to be a good social worker/social educator?

8. What is the best thing about Social Education/Social Work in Catalonia?

Note: Reprinted from Cavalcante M.T.L (2014). International Perspectives on Social Innovation. Assessment Guidelines

\section{B. Dream Phase:}

In this phase students had to prepare a short essay in English, Spanish or Catalan on how they would like Social Education and Social Work to be in the next 20 years, drawing inspiration from the positive inputs of their discovery phase, and their essay was expected to refer to these positive feelings. They were given a guideline with a number questions in English in order to help them do this (Table 4).

C. Design Phase:

For the design phase students had to consider their dream and think about how it would be possible for Social Education and Social Work to be as they described them 20 years from now. Each group had to define the conditions to reach their vision. They were asked to give a list of 4 priorities for at least 4 different areas, such as education, technology, work conditions, professional profile, jobs or new competences. For each priority, they had to define actions that would help to accomplish what they defined as their expected future or dream. Once again, this essay could be delivered in English, Spanish or Catalan.

D. Delivery Phase:

Finally, for this phase, they were expected to deliver a final product in English on the Internet expressing the overall idea of their AI project. This final product could be a video, a drawing, an animation, a comic, or a presentation. It had to contain:

- The group's positive appreciation of social work/social education (from interviews, discovery phase)

- The vision they have set for social education/social work (their dream)

- The route to get there (the design)

- Their final appreciation of the entire project

As previously mentioned, the Moodle platform was used to share material and deliver essays, but all through the course the Facebook page was definitely the main resource for collaboration and content sharing.

Table 4 Dream phase guideline

How would you like Social Education/Social Work to be 20 years from now?

What would you like to be doing as social workers/social educators 20 years from now?

What kind of projects will social workers/social educators be designing and working on?

What kind of technologies will be employed in these projects?

A social worker/social educator of the $21^{\text {st }}$ century must...

Note: Reprinted from Cavalcante M.T.L (2014). International Perspectives on Social Innovation. Assessment Guidelines 


\section{Results}

The results can be described in terms of a) content assimilation, b) technologies incorporated into the learning process, c) language skills and d) methodological experience.

Regarding content assimilation, a summary of the main achievements in each phase is illustrative.

A. Discovery Phase: Students carried out more than a hundred interviews: with their supervisors at their internship centres, with professional colleagues and with teachers. They were surprised at the interviewees' positive impressions of their professions and were impressed by some successful professional stories. It proved possible to identify a number of common attributes and qualities of a good professional. Some students acknowledge how difficult it was to focus on positive traits, given the temptation to voice complaints. The general feeling after the session of sharing the interview impressions was of being proud of their chosen profession. There was a positive atmosphere and enthusiasm for taking the next step.

B. Dream Phase: Students essays set very high aims in a positive scenario, but were not naïve. Questions such as sustainable development, political action, new forms of democracy and social participation appear on their agendas for the next 20 years. It is interesting to note that many groups mentioned political advocacy as a promising professional activity. Also, they mentioned personal aims, such as "being happy in my profession", or "making a living in my profession".

C. Design: All of the groups set priorities in their own education, mentioning the need to incorporate technological issues in their curriculum, and suggesting that the university should offer joint interdisciplinary subjects among its degrees.

Innovation, technology and language competences were highly valued, along with programmes to favour professional mobility. Some specific actions to promote technological skills were mentioned, such as the development of drone technology projects by social educators. With regard to political actions, students suggested specific actions at the community level and the strengthening of bonds with social movements.

D. Delivery: Students presented their final essay directly on the Internet. The final message of each group offered an enthusiastic view of their future profession, with some concrete suggestions for arriving at this desired future. All of the presentations achieved an acceptable English level.

Regarding the incorporation of technologies into the learning process, all of the students were familiar with the Moodle platform and to Facebook. The innovative aspect was to deliver content trough the Facebook page - in order to get up to date with the subject students should follow and share material on the social net instead of downloading presentations from the Moodle platform as they were used to.

The most challenging requirement was to deliver a final media piece on the Internet. The objective was to favour creativity and to share their results. There were no pre-set expectations regarding the use of the multimedia tools. As those technologies are not usual in their career, expectations were not high. The only requirement was "share your video on Internet". The results have shown that we could perfectly incorporate technological requirements on our assessment guidelines not only in this subject but in others of their curriculum. The technologies used to present the final project were 
Moviemaker and presentations with Powtoon, Videoscribe, Magisto and Prezi. Students shared their videos on the subject's Facebook page and, in some cases, on their own YouTube account. There were some very high level video productions, with outdoor locations and a drone camera. Students also had to deal with copyright issues in selecting the material to be used in their video, a constraint that is worth mentioning, but one that also brought an interesting discussion into the learning process.

In relation to language skills, allowing intermediate tasks to be delivered in Spanish generated a predisposition to work. In the supervision sessions it was possible to observe that English was not an issue during class time, and students were grateful to join a multilingual class in which they were not obliged or forced to speak in English. Students with some grasp of English were able to feel comfortable about making mistakes and about helping their colleagues in the tutoring sessions by translating. Students with a low level of English were surprised to realize they could learn content and participate despite their inability to speak the language. In addition, the exposure to attractive international material played a part in enhancing their awareness of the importance of improving their English competence beyond academic requirements.

Concerning methodology, the tool itself was also a learning experience, as students are now able to use AI for promoting social change in the institutions or communities they will be working with. This was a "learning by doing" experience, and constitutes an additional skill incorporated into the student's professional tool box.

Regarding the teacher's evaluation of the student's progress, the final grades exceeded expectations, with $30 \%$ obtaining As and $42 \%$ Bs. No student failed the course, and the dropout rate was $10 \%$, due in every case to enrollment issues not related to the subject. The Continuous Assessment model provided students with supervision and tutoring and the assessment criteria was based on the expected competences and learning results (Table 1).

The student's perceptions of their learning process was also taken into account as we applied a tool to measure their perception of the acquired competences. Students were asked how they would assess their final competences on a scale from 1 to 10 . The participation rate was $43 \%$ (50 students). The self-assessment tool indicated that $86 \%$ of participants considered that they have acquired the capacity to identify and describe Social Innovation on a very satisfactory level (7 and above). Regarding the development of creative thinking and envisioning, $78 \%$ of the respondents considered they had scored 7 and above out of 10, and $40 \%$ (20 students) considered they had scored 9 and above.

\section{Discussion}

The main contribution made by this work is the successful combination of three innovative aspects in a replicable format that can be applied to other disciplines: a multilingual environment, a new and promising content and a positive methodology.

The multilingual environment created an atmosphere of confidence by using an inclusive approach that allowed students to innovate and create content in English something that was unthinkable on the first day of class. As mentioned at the beginning of this article, the development of a subject in English in a non-native environment can be intimidating and stressful. In our experience, English constituted part of the communicative environment, but was not an obstacle. Within a few years it may well be possible to increase the amount of spoken English in class. In the 
meantime there is a generation of students on the way to enhancing their English communication skills. That said, by the end of the semester social work and social education students were uploading their videos on the Internet, and declaring in English what kind of social work/social education they want for their future. Moreover, they also used innovative tools on the Internet to encapsulate their message and their discourse, instead of reproducing the same presentation mode they have been used to.

At the same time, we also challenged our students to think about how to innovate in their professional field. Finding and dreaming about social innovations in different parts of the world was motivating and enabled them to "think out of the box". For instance, learning from social projects that are using drones to teach children within the autism spectrum opened up new interests and revealed work possibilities. In light of this, the final products reflected a very positive image of the perspectives of innovations in the social sector as well as their willingness to innovate as future professionals.

In addition, in their design phase (the planning for reaching the expected future) the students included some aspects directly related to new needs on their curriculum. This should also foster curricular innovation on our part, for instance, by responding to their interest in the application of information and communication technologies to social education or social services management. Another curricular aspect that demands the faculty's attention is political advocacy and community empowerment, two fields in which the students definitely hope to be working 20 years from now, but which are currently undergoing major changes.

Finally, the methodology of the AI project favoured a positive engagement with their future profession. Third-year students usually form their first clear impressions of the profession as they begin their internships. The current context of economic constraints, fewer resources and low budgets presents them with a reality that can be tough to deal with. It can also be seen as a threat to their chances of future employment, thus engendering anxiety. By using scenarios and resources from the Appreciative Inquiry Methodology, we invited students to discover, dream and design a social destiny that is worth working for.

Acknowledgments

We are especially grateful to Xenia Orgielewski for sharing her knowledge on the Appreciative Inquiry Methodology and to Eddy Van Hemelrijck and Pieter Lievens from Karel de Grote University College for inspiration.

Funding

This work was funded by Universitat Ramon Llull - Ajuts Universitaris Ramon LLull - Projecte Tractor.

Authors' contributions

All authors have made substantial contributions to conception and design, analysis and interpretation of data, have been involved in drafting the manuscript and revising it critically and have given final approval of the version to be published. MTC conceived the study and the design, carried out the implementation and coordinated the draft process. GRB contributed to conception, participated in the design of the study, performed the assessment analysis and helped to draft the manuscript. GRG contributed to the conception, participated in the design and coordination and helped to draft the manuscript. All authors read and approved the final manuscript.

Competing interests

The authors declare that they have no competing interests.

\section{Declarations}

This article is original and has not been formally published in any other peer-reviewed journal, is not under consideration by any other journal and does not infringe any existing copyright or any other third party rights. The article contains nothing that is unlawful, libelous, or which would, if published, constitute a breach of contract or of confidence or of commitment given to secrecy. 
References

Bean, J. C. (2011). Engaging ideas. The Professor's guide to integrating writing, critical thinking and active learning in class (Jossey bass higher and adult education series). San Franscisco: Wiley.

Cavalcante, M.T.L (2014). International Perspectives on Social Innovation. Subject's syllabus 2014-2015. Facultat d'Educació Social i Treball Social Pere Tarrés Universitat Ramon Llull. Barcelona. Spain.

Cavalcante, M.T.L (2014). International Perspectives on Social Innovation. Assessment Guidelines 2014-2015. Facultat d'Educació Social i Treball Social Pere Tarrés Universitat Ramon Llull. Barcelona. Spain.

Cooperrider, D. L., \& Whitney, D. (2001). A positive revolution in change: appreciative inquiry. Public administration and public policy, 87, 611-630.

Halbach, A. \& Lazaro, A. (2015). The accreditation of English language level in Spanish universities. La Acreditación del nivel de lengua Inglesa en las Universidades Españolas. Actualización 2015. Universidad de Alcalá. British Council. Madrid. España.

Lasagabaster, \& Ruiz de Zarobe, Y. (2010). CLIL in Spain. Implementation, results and teacher training. Newcastle: Cambridge Scholars Publishing.

Lievens, P. (2014). Wellbeing and economic growth intensive programme (Guide book for students). Antwerp: Karel de Grote University College (KdG). March 24 - April 42014.

LLEl 2/2014, del 27 de gener, de mesures fiscals, administratives, financeres i del sector públic. Article 211. Acreditació dels coneixements d'una tercera llengua [LAW 2/2014 of 27 January, on fiscal, administrative, financial and public sector measures. Article 211]

Marsh, D. (2001). Using languages to learn and learning to use languages. Finland: University of Jyväskylä.

Mulgan, G. (2007). Social innovation: what it is, why it matters and how it can be accelerated. Skoll Centre for Social Entrepreneurship. Working paper. Oxford Business School. The Basingstoke Press. UK

Newton, B. \& Hartley, C. (2005). Appreciative enquiry: a practical guide. Institute of Employment Studies. IES. Research Networks. Brighton, UK

OCU Organización de Consumidores y Usuarios. (2013). Learning languages - the pending subject Aprender Idiomas la asignatura pendiente. Compra Maestra $n^{\circ}$ 377. Spain. January, 2013. https://www.ocu.org/organizacion/prensa/ notas-de-prensa/2013/encuesta-ensenanza-idiomas.

Standards and Guidelines for Quality Assurance in the European Higher Education Area (ESG). (2015). EURASHE Brussels, Belgium.

Submit your manuscript to a SpringerOpen ${ }^{\circ}$ journal and benefit from:

- Convenient online submission

- Rigorous peer review

- Immediate publication on acceptance

- Open access: articles freely available online

- High visibility within the field

- Retaining the copyright to your article

Submit your next manuscript at $>$ springeropen.com 